\title{
Una lectura de El Gran Vidrio de Marcel Duchamp y La Nueva Novela de Juan Luis Martínez como articulación meta-poética y auto-reflexiva
}

\section{A Reading of Marcel Duchamp's The Large Glass and Juan Luis Martínez's La Nueva Novela as a Meta-poetic and Self-reflective Articulation}

\author{
Andrés Cáceres Milnes \\ Universidad de Playa Ancha, Valparaíso \\ acaceres@upla.cl
}

\section{Resumen}

El presente artículo tiene por objeto investigar y analizar el texto La Nueva Novela de Juan Luis Martínez en una articulación en bisagra con la obra El Gran Vidrio de Marcel Duchamp a través de la noción apariencia/aparición como elemento de transparencia textual. Desde esta perspectiva, se propone una lectura meta-poética y auto-reflexiva en el marco de un mundo moderno puesto en crisis.

Palabras clave: auto-reflexividad, deconstrucción, meta-realidad, La Nueva Novela, El Gran Vidrio.

\section{Abstract}

This article intends to analyze Juan Luis Martínez's La nueva novela following a close articulation of this text with Marcel Duchamp's work El gran vidrio under the notion of appearance/apparition, understood here as an element of textual transparency. From this perspective, a meta-poetic and self-reflexive reading is proposed in the context of a modern world in crisis.

Keywords: Self-Reflexion, Deconstruction, Meta-Reality, La Nueva Novela, The Large Glass. 


\section{Primera reflexión: Deconstrucción}

La deconstrucción es una estrategia textual que vamos a tomar como un modo de lectura. No intenta captar el contenido unitario de las obras de Marcel Duchamp, sino el funcionamiento de las figuras y las relaciones textuales en una lógica de análisis que tiene como postulado el nexo de la mirada, el lenguaje y el signo artístico. Se trata de configurar una especie de dispositivo abierto incompatible con el concepto de estructura. Reflexión fragmentaria y deconstructiva que deriva hacia la unión del pensamiento de la huella con la diferencia en un juego sistemático de espaciamiento, donde los elementos se imbrican a un nivel de productividad connotada.

El programa derridiano introduce el concepto de la différance, que nos remite al movimiento, o sea, diferir por desplazamiento, remisión y retraso, como una actividad de producción que se construye en el fundamento de la noción de puesta en escena. La actitud artística manifiesta una preocupación por el procedimiento de la construcción o, en otros términos, el proceso de la obra abierta. Pero la mirada apunta a la lectura de un espacio-devenir que hace posible el tránsito generativo desde la diferencia hasta los efectos de transformación por vía de la intuición y significación.

Espacio, porque el valor semántico está definido por el desglose del cuadro, verdadero signo que se orienta hacia la especialidad del lenguaje mismo de la obra. En este sentido, el cuadro es un texto expansivo, donde la deriva del pensamiento trama la différance en el deslizamiento del logos hacia la conciencia emancipada. Nos encontramos con una voluntad artística de situarse en un más allá de la apariencia, un propósito de desmembramiento de la matriz dogmática de la tradición. Dado el logocentrismo, es imposible no pensar en cuestionar los presupuestos de la verdad canónica. La verdad convencional de los objetos tiene en la palabra la torsión deconstructiva en tanto que despliega una ilusión cerebral de la realidad. Vale decir, la palabra sangra al despojar del objeto canónico y tradicional su condición puramente retiniana. La experiencia del límite desborda la inocencia del lenguaje, (re)situándolo en el espacio del pensamiento como gesto deconstructivo.

Duchamp está trabajando con el lenguaje y ha puesto en cuestión la representación visiva desde el punto de vista fisicalista de la certidumbre perceptiva. Además, si el cuadro es un texto, entonces, la pintura es un grafismo equivalente a la escritura. De modo que está la noción de transferencia y de signo extensivo, transversalidad epistemológica entre literatura y pintura, que funciona como bisagra por medio de una escritura que se decanta hacia lo informe e inacabado. Escribir evidentemente es un asunto de devenir que desborda la materia. Devenir es encontrar la zona de la diferencia mediante un "entre", que sirve de gozne en la especialidad del cristal (Gran Vidrio). Espacio tenso y liso, cerrado y replegado sobre sí mismo, que como signo se abre a la polisemia de una mirada plural a "la novia" y "los solteros". Mientras ella sujeta el hilo de su soltería, ellos salpican su erotismo. 
Desde la experiencia duchampiana, la visión del texto tiene el placer de la torsión, de la transgresión. Por de pronto, sería un texto de voces que tuercen las convenciones y saberes tradicionales. Esta puesta en cuestión de las apariencias eternas y hegemónicas (verdades) supone el desmontaje de la voluntad, que se orienta hacia la virtualidad de la aparición en una relación de palabra-imagen-objeto.

La reflexión duchampiana tiene en la visualización del fragmento la práctica deconstructiva de la narratividad lineal. Cruce de palabras e imágenes que soportan una mirada fisurizada y en intersticio como discurso rupturista, donde el concepto de verdad ligados al logos y al signo es puesto en cuestión por el pensamiento de la différance en tanto huella o marca que desborda devenires, puntos de fuga y desterritorializaciones. Es el diferimiento como espaciamiento y desviación de la palabra respecto al objeto. El diferir es la instancia de lo originario mientras la différance es lo impensado.

El lenguaje duchampiano tiene la conspiración del silencio, murmullo incesante entre la imagen y la palabra que llega a ser un gesto litúrgico, propio de una escritura que se prolonga en obra gráfica, en cuadro que no imita porque es simulacro y virtualidad literaria. De este modo irrumpe el lenguaje del pensamiento, que confirma el distanciamiento irónico de la palabra. Ahora no sólo apunta, sino que hace gestos y señas de transgresión, es decir, el lenguaje para Duchamp es un dejar ser. Pero este desborde (erotismo) constata los límites del lenguaje en la factura de un mundo que se desfonda en la experiencia de lo impensado, como diría Foucault. La transgresión dice lo que siempre quiso negar: las palabras conspiran con el silencio en la medida en que el lenguaje delira, irrumpiendo fuera de sí en un mundo que se reconstituye en la profanación y en la reiteración de un permanente recomenzar. Indefinidos pliegues de sentido que afloran en la superficie como puntos de fuga entre lo visible e invisible. Duchamp está cuestionando los espacios recesivos que se producen entre la imagen y el ojo.

La différance hace que la intuición y significación no sea posible más que si cada objeto presente (nivel de apariencia sensorial) se relaciona con otra cosa (nivel de aparición no retiniana). Esta trama de reapropiación entre las palabras y los objetos tiene la deriva de la ruptura. En esta presencia está la sombra de su propia ausencia. Vale decir, la différance es una estrategia que imbrica la lectura y escritura a través de un receptor que activa el movimiento extensivo y diseminador entre el lenguaje, los modos de decir y los modos de ver. Se deconstruye la autoridad canónica de un logocentrismo vigilante por medio de un desvío y diferimiento que impide cualquier horizonte de clausura. Ahora el texto como tejido expansivo e impensado se produce en la transformación de otro texto.

La ley de lo impensado es la liberación de la palabra en ese silencio pictórico, que sólo se atiende cuando todo se escucha. La materialidad de los enunciados en el cruce entre narratividad y visualización es el objeto pulverizado y arrojado al aire virtual de una nueva impugnación y transgresión, que es el efecto del azar del lenguaje 
instalado con todo su poder en el interior de lo que dice el texto. El azar no es otra cosa sino una forma de transmutar en discurso el impensado murmullo incesante de la transgresión y el improbable encuentro de las palabras y las cosas. El discurso se ve sometido al azar de su propia materialidad.

El fin es poner en crisis la representación, cuestionar la rutina convencional mediante la preocupación por una nueva designación, dada en operaciones de descontextualización y recontextualización de los objetos. Esta crisis tiene el gesto transgresivo que concierne al límite. En este juego entre el límite y la transgresión está el espacio de la incertidumbre. Es la glorificación del desborde: de la palabra encadenada al brinco de lo impensado.

La escritura en su différance es una instancia fundamental para llevar a cabo la deconstrucción de la presencia o apariencia, entendida como privilegio de la linealidad o narratividad de la imagen gráfica. La idea es desestabilizar la hegemonía logocéntrica a través de un diferimiento configurado por el proceso de creación. Pliegues de sentido por vía de una lógica atribuida a la huella o traza suplementaria y transgresora de la aparición.

Derrida habla de una archi-escritura. Concepto diferente a como entiende la expresión 'escritura' el pensamiento logocéntrico (agregado o revestimiento externo de la presencia originaria: la escritura como modo vicario). Se trata de constituir una escritura que implique la transgresión de la noción canónica de representación, pues en la vanguardia se trata de leer y escribir de otra manera. Ahora la escritura se produce en el juego y el azar. La deriva de la différance como un programa que se despliega en la archi-escritura, ámbito que hace estallar la habitualidad semántica y perceptiva de las palabras en su relación con los objetos.

Del mundo como espacio de inscripción de una escritura tradicional a la apertura y distribución espacial de los signos en su juego regulado por el azar y la ironía, es el corrimiento propio de una archi-escritura, concebida como condición de posibilidad de todo lenguaje. En consecuencia, el lenguaje como una escritura no será accesoria ni secundaria, sino la articulación de la différance.

Tomar la deconstrucción derridiana como una estrategia textual significa un intento por fisurizar los límites del texto duchampiano por medio de una raspadura que deje leer la sombra y mirar en intersticio, revelando un corrimiento alusivo a la escritura. "Otra" lectura que dé cuenta de los pliegues de ilegibilidad inscritos en el sistema significante a través de una operación de desmontaje y deconstrucción, poniendo en la mira la dimensión logofonocéntrica del andamiaje estructuralista: leer y mirar lo ilegible. Es el desencadenamiento de la deriva en un gesto doble (escritura/lectura), que articula verdaderas estrías en un movimiento de deshabituación de los hábitos perceptivos del lector, de relaciones y sumisiones, que raspan la seguridad de lo decible, y en el marco de la transferencia de saberes producto de que la palabra y la imagen está en una puesta en bisagra epistemológica: pintura literaria/literatura pictórica. 


\section{Segunda reflexión: meta-realidad}

Marcel Duchamp (1887-1968) desempeñó un papel importante en la emancipación del arte moderno como gestor de los movimientos de vanguardia. La producción rebosa una unidad que está sustentada en un variado mundo de influencias que repercute tanto en su modo de vida como en las reflexiones y creaciones artísticas. Él asume un rol intuitivo en la configuración anti-convencional del arte. Además, la experiencia analítica remite el arte a la tradición neoplatónica (el mundo de las ideas) y a la valoración intelectual (meta-realidad).

Estas dos dimensiones dan cuenta del acto de transmutación de sus obras, producto de un proceso mental de creación que busca el desplazamiento de los límites de lo posible. En esto consiste el umbral de la modernidad duchampiana. La acción de crear -importa el proceso y no el resultado-implica la auténtica trascendencia del artista. De ahí su obsesión asceta por el hacer artesanal. Ardor subversivo contra el lenguaje canónico y mirada perversa de la realidad retiniana. El hilo conductor procede de una perspectiva de ampliación afirmativa y de una posición de distancia irónica y anti-emotiva del texto plástico, alejada del fisicalismo óptico como método de aproximación.

Las obras de Duchamp deben ser leídas de acuerdo a dos fases: una receptiva, donde el sujeto-lector es fundamental en tanto que debe completar el sentido de la obra, y otra procesual, en el marco de las palabras, las imágenes y los objetos que se ensamblan desde el ámbito de lo impensado. De esta manera, asistimos al azar permisivo de significados, que entrelazan artefactos entre lo permanente e imponente y lo efímero e ínfimo. En esto reside el ironismo que Duchamp denomina de afirmación (humor). Dirá que "[...] mi ironía es la de la indiferencia: metaironía” (Duchamp 17).

Mirada y lenguaje, imagen y objeto van de la mano. Esta lectura en bisagra entrama las palabras y las cosas en un giro lingüístico que da preeminencia al discurso de la desobediencia, murmullo incesante de una transgresión que ironiza el significado de la certeza. Pero que, a la vez, es un signo positivo porque poetiza el lenguaje del conocimiento a partir de la ambigüedad y virtualidad en la significación críptica o en la figuración de lo posible.

En el fondo, es una tentativa por repensar el mundo al margen de la fisicalidad de los objetos. Se trata de que las palabras proyecten sus propias sombras en su relación con las cosas, moldes que tienen su punto de apoyo en la fecundidad y productividad de un arte pictórico-literario, que hace de la subversión su propio claroscuro anti-estéril. Esto, a partir de la máquina (imagen y encarnación de la época post-aurática) y el azar (nueva divinidad). Duchamp vive una aventura mental en un contacto entre la máquina del deseo y el azar, constituido por la pasión del juego (¿o el juego de pasiones?). De ahí que se considera la obra duchampiana como el signo de la meditación entre el hermetismo y el intelectualismo. 
Él manifiesta su rechazo por la apariencia sensitiva. Más aún, sobrepasa la realidad convencional y la hegemonía del discurso canónico. Aquí surge la noción de meta-realidad, que supone el tránsito hacia la inmaterialidad y el principio del humor irónico. Auténtica des-teorización centrada en la transmutación de los estados mecánicos a través de la construcción de un universo de imágenes en movimiento. Por ejemplo, su etapa cubista con Portrait on Dulcinée, 1911.

Para Duchamp el arte es un trabajo de laboratorio. El deseo era romper las formas, descomponiéndolas. Y, su obsesión, reducir la silueta a una línea maquínica. Pero, al mismo tiempo, buscaba asomarse en el interior (la sombra) del objeto. Vale decir, quería alejarse del acto físico de la pintura, "[...] a mí me interesaban las ideas -y no simplemente los productos visuales”(153). Él pretendía devolver la pintura al servicio de la mente. Indudablemente que su obra quedó definida como intelectual y literaria. La palabra se emancipa en una actitud de búsqueda permanente de una meta-realidad por medio de una imaginación delirante.

Lo que está haciendo es deconstruir la representación canónica desde la visualidad. Entonces, el receptor activa la polisemia del signo pictórico mediante operaciones de recorrido sobre una superficie que se abre a pliegues de sentido. Esta deriva desborda la narratividad de la imagen a través de un diferimiento que traza una escritura alegórica, que se produce en el juego y el azar. Es “otra” lectura, la del devenir. En este contexto, Duchamp valora el azar para introducir la perplejidad y provocar desenlaces imprevistos. El placer del texto duchampiano está en la deriva y el devenir como espacio de la diferencia. Escritura anti-logocéntrica, que irrumpe en la percepción de "otra" realidad por parte del sujeto. Vale decir, es recepcionar la entidad de los objetos como algo fluyente, que sólo tiene la quietud del instante fugaz. Así, la obra se convierte en una aparición, molde referido a la apariencia cambiante de la realidad. De esta manera, la obra camina hacia la configuración del deseo y el arte se conceptualiza en el coeficiente diferencial entre lo deseado (concebido) y lo conseguido (lo realizado).

El desencadenamiento de la deriva raspa la certidumbre de los saberes canónicos, originando el placer de la torsión entre las palabras e imágenes y en una transversalidad epistemológica que ensambla pintura y literatura. Ahora el hedonismo del pintor es sustituido por la manualidad del artesano a través de un plan que, 'pensando con los ojos', constata la representación de la realidad de acuerdo con el discurso cultural predominante. Es el paso a la transformación poética de la realidad, pero ubicándose en el entramado de las palabras y las cosas.

A Duchamp le interesa la manualidad del artesano a través del estudio de una nueva técnica alusiva a un dibujo y arte seco. Por eso, el nuevo arte estaba en el objeto mecánico, donde él empezó a valorar la exactitud, la precisión y el azar como una manera de afectar la materia gris, la comprensión anti-retiniana y la instauración de una meta-realidad. Expresión mental que posee la expansión del texto en espiral. Escritura de la transgresión del pensamiento logocéntrico y de la noción de representación por medio de la ironía. 
Con el objeto mecánico se trata de incorporar un elemento maquínico trivializado sobre el cuerpo de la tela o el cristal, para que funcione como máquina deseante. Sin embargo, se produce una línea de fuga maquínica. Des-territorialización que en Duchamp adquiere una categoría aleatoria que induce a un cambio de rol: es abstracción pura, ni figurativa ni proyectiva, sino líneas de intensidades recurrentes (Deleuze y Guattari 400). Esta recurrencia relaciona la máquina-vidrio con los restos y residuos de los artefactos ya hechos. En otras palabras, es el "sistema solar" rodeado de los "planetas" como energías o intensidades que giran en la Vía Láctea (cuarta dimensión o novela de anticipación $)^{1}$ por medio de una verdadera imaginería mecánica que libera al objeto de los límites de la palabra.

El proceso creativo de Duchamp transita del arte en estado bruto al arte refinado por el espectador. En este tránsito está la noción de auto-reflexividad. Es lo que él denomina "coeficiente artístico".

El fondo de obra duchampiano adquiere un aspecto diferente cuando el espectador se halla en presencia del acto de transmutación. El paso de artefacto a obra de arte es un efecto de transubstanciación que se da entre el espectador y la obra estética (Duchamp 163) según un modo de lectura que da cuenta de la crisis de la noción de analogía y representatividad. Surgen puntos de fugas. Esta desconexión permite que se origine otra percepción, anti-retiniana: pérdida de la posibilidad de reconocimiento y certidumbre, pero augurio de una meta-realidad, que se sustenta en el mundo de las ideas y en la dimensión intelectual.

\section{Tercera reflexión:}

\section{Sistema Solar y sus planetas (novela de anticipación)}

\section{Soporte.}

Duchamp se sitúa en un territorio intelectual más allá de la realidad visiva. Nuevo diagrama que elabora una estampa artística original caracterizada por cruces y transferencias producto de "otros" circuitos que (re)plantean el espesor discursivo en la relación referente y significado. Ahora el circuito pictórico transita por el ejercicio analítico, dejando de lado la articulación representativa con el propósito de abocarse a una reflexión metalingüística de la obra de arte.

El dispositivo analítico posee un doble aspecto. El mundo de las ideas con su respectiva ejecución y el mundo de la escritura con la huella en el discurso diferencial. Conceptualización y procedimiento técnico que gira en torno a la noción de construir y elaborar como nuevo paradigma que desplaza el modelo clásico de la representación

1 Hoy se habla de la cuarta dimensión del espacio que rompe con la concepción euclidiana del espacio tridimensional: la imaginación que adquiere su concreción espacial vía tecnología (realidad virtual). 
e ilustración expresiva por: a) un proceso de mutación (obra inconclusa, El Gran Vidrio); b) una voluntad creativa y no meramente reproductiva; c) el soporte artístico es el proceso y no el producto como fin. Vale decir, se produce un desmontaje (deconstrucción) de la estampa clásica como problematización del referente y significado. Ahora la tensión analítica se encuentra en el dispositivo significado-referente en la relación obra-texto.

Este giro provoca una pérdida de la representatividad del mundo exterior, pone en cuestión el carácter ilustrativo y subvierte el orden establecido mediante la creación de una nueva estampa: la meta-realidad. El verdadero protagonista del relato pictórico es el objeto desplazado por los límites de lo posible como representación cerebral. La figuración de este posible es el objeto revelado por la palabra en un acto de transmutación poética que se resuelve en la conciencia.

\section{Adverbio}

La nueva lógica duchampiana es por yuxtaposición e integración de las palabras y los objetos a través de la transparencia de las imágenes y encabalgamiento de sentidos. Es la lógica del adverbio emblemático: incluso, también, mismamente. Los objetos liberan su monogamia asociada canónicamente a una cierta función e idea para ser también apreciada por una nueva lectura. Se pone a prueba la noción de límite. Por ejemplo, el urinario como objeto se desmonta del valor orgánico y adquiere incluso valor por la simplicidad de sus líneas.

La relación de las palabras y las imágenes tiene en el adverbio la propuesta de una producción metafísica, que encabalga el sentido de transmutación o distorsión de las cosas a la luz de las obsesiones duchampianas: el descrédito de la ciencia positiva, la seriedad solemne de la Verdad y la preeminencia del amor y el erotismo. Lo que está haciendo Duchamp es una reflexión, un discurso sobre la obra desde la noción de ruptura. En este sentido, la nueva lógica integra el lenguaje del pensamiento con el gesto adverbial de la inclusión por vía de la integración y encabalgamiento. Por eso, la tesis que planteamos y que está en torno de la producción de Duchamp es la siguiente: el astro solar con una serie de planetas que giran a su alrededor es un movimiento circular de señas duchampianas que corresponde a la relación centro-periferia entre el Gran Vidrio y los ready-mades, incluso admite también la Caja Verde y Etant donnés. Uno, visto como museo portátil, que sería la síntesis desplegable de su producción, y el otro, como un dispositivo óptico. En su conjunto, el propósito es proyectar un encabalgamiento de sentidos, donde el área de interés no es el aislamiento, sino la integración por yuxtaposición entre lo masculino y femenino, erotismo y sexualidad.

Marcel Duchamp opera artísticamente con bisagras giratorias que funcionan como goznes semánticos, lo que modifica la apariencia de las cosas y da a sus obras un carácter de intersticio. La proyección física, entonces, se desarrolla por vía de encuentros instantáneamente suspendidos que absorben una valoración y un análisis de la discursividad del arte contemporáneo desde una mirada anti-retiniana de la obra 
y de acuerdo a una estrategia metodológica por inclusión adverbial, o sea, el análisis toma en cuenta las piezas del relato para que vayan adquiriendo valor en el contexto global de la máquina narrativa, también.

\section{Ready-made (1913-1921): planetas}

El ready-made es algo ya hecho o fabricado previamente. El artista elige los objetos del universo industrial o natural de acuerdo con una neutralidad estética y la apatía visual. Esta operación con los objetos tiene una vocación de ejemplaridad en tanto que registra la discontinuidad entre las palabras y las cosas, disociación semántica y acto transgresor de la convencionalidad artística, que se une con la función irreverente e iconoclasta y con el tema de la elección del artefacto. Elección que se sustenta no en la atracción, "[...] sino en la absoluta indiferencia, en la neutralidad, es decir, en un absentismo estético total, en una absoluta anestesia" (Touchen 17). Sin embargo, como señala Juan Antonio Ramírez en Duchamp el amor y la muerte, incluso de 1993, debemos tener en cuenta también otros factores: a) distinguir el artefacto según el grado de rectificación y la complejidad de los ensamblajes; b) los temas de corte literario que poseen; c) el grado de exigencia en la manipulación: para leer y mirar, manipulación recomendable y obligatoria; d) las interconexiones temáticas y técnicas que ligan la obra duchampiana, revelan que son episodios o experimentos parciales unidos a una intención global, o sea, la ilación ready-made y el Gran Vidrio es a planeta y sistema solar; la naturaleza estética de cada readymade; f) el parentesco con algunos experimentos literarios; g) la estructura común que poseen, es decir, es un producto ya elaborado, que el artista escoge con el propósito ambiguo de realzar sus valores estéticos hasta ese momento ignorado $y$, a la vez, desacreditar la estampa monogámica y canónica consagrada a la relación palabra-imagen-objeto. En el fondo son chistes objetuales que, en el plano de la ironía, afirman una técnica de distanciamiento artificial en un juego de desplazamiento de posiciones y de acuerdo a un cambio del ámbito mental. Objetos que tienden a desestructurar al sujeto para aproximarlo a un estado de ensoñación: shock perceptivo que rompe el orden natural.

El ready-made pone en crisis la designación ilustrativa y expresiva a través del diagrama de la torsión y deconstrucción. La nueva estampa tiene el placer de la deriva del significado respecto al referente. Es el tránsito de lo metafórico a lo metonímico, donde el objeto con su huella, se nombra a sí mismo (tautología).

Estos artefactos (La rueda de la bicicleta, Tres zurcidos patrón, Portabotella, etc.) funcionan con significados encabalgados, es decir, al sentido primario definido como la función usual y monogámica del objeto se le adhieren también otras connotaciones técnicas. Por ejemplo, la clave sexual enganchada con la iconografía del astro solar que es el Gran Vidrio. 
Un simple utensilio como el peine se convierte en una máquina especulativa, un mecanismo para escaparnos a la cuarta dimensión. Del Peine metálico (1916) pasa a la Tonsura (1921), clara alusión al lugar de la pintura: el cerebro. El arte aspira a ser una cosa mental. Lo mismo sucede con el erotismo (Ramírez, Duchamp el amor y muerte, incluso 39). En este sentido, a Duchamp lo seduce lo improbable e impensado de las insinuaciones. Por ejemplo, la funda vacía de una máquina de escribir Underwood se concibe como una falda femenina en Pliant... de voyage (1916), verdadero artefacto femenino. Estos artefactos son trampas temáticas donde tropieza la inocencia monogámica del objeto, desencadenando un movimiento deconstructivo en la perspectiva de crear también otras huellas originales que estampen líneas de intensidades maquínicas amorosas. Evocaciones femeninas que afloran además con los ready-mades suspendidos. Objetos para colgar como la Percha (1917), la Escultura de viaje (1918) y Aire de París (1919) apuntan hacia la fragilidad del universo femenino en relación con el giro planetario en torno al "sistema solar" del cristal.

El ready-made L.H.O.O.Q (1919) es distinto a los objetos industriales elaborados. Se caracteriza por su intención temática de índole "desmitificadora respecto al arte sublime de la pintura" (Ramírez, Duchamp el amor y muerte, incluso 46). El cuadro de La Gioconda con atributos masculinos - atrapada en la sonrisa y en la enigmática femineidad-es un hombre. Ella es la persona que mira. Pero, hay una representación irónica: ella es él. Mirar un ready-made es para leerlo con sarcasmo en tanto que no es una máquina manipulable. Esta mirada se asocia con los testigos oculistas del Gran Vidrio: vigilar con ojos panópticos el erotismo y la sexualidad.

El tema predominante en el relato de los ready-made es fundamentalmente sexual (instintos primarios). De ahí, el gozne giratorio con el "sistema solar" del Gran Vidrio. Por otra parte, la connotación amorosa no está sólo en la mirada, sino que la iconografía también destila un lenguaje-devenir a través del placer del aliento, olor y temperatura como vemos en Belle Haleine, eau de voilette (1921): mirar y leer con ojos anti-retinianos para hacer visible lo invisible.

El caso de la Fuente (1917) sintetiza todo lo dicho. Es una provocación a los límites del lenguaje, pues suscita el murmullo de la transgresión mediante el desborde del tema de la reivindicación del urinario como un objeto industrial bello. Este artefacto incluso es una máquina sexual, que connota un re-envío especular o doble uso escritural a nivel del género: aprovechamiento energético de las caídas de los efluvios corporales masculinos y, a la vez, erotismo femenino como recipiente de las cascadas naturales del hombre. El hombre arriba, la mujer abajo, en un movimiento circular y masturbatorio, que se ensambla con la especulación amorosa del Gran Vidrio.

El urinario es un ready-made masculino como la funda vacía de la máquina de escribir es femenina. Una integración por yuxtaposición, donde el gesto adverbial de cada artefacto es un episodio que tiene como tema el género, pero en la perspectiva metonímica de la figura del "planeta" con respecto al "sistema solar" como estampa original del amor. 


\section{El Gran Vidrio (1915-23; 1936): Sistema Solar}

Raymond Roussel le mostró a Marcel Duchamp el camino del Gran Vidrio con la representación de la obra Impressions d’Afrique (1912). Esta obra anti-romántica y anti-naturalista -llena de artilugios y máquinas-indica que es posible realizar un trabajo literario alejado de las convenciones del género. Esta experiencia le valió señalar que "como pintor, era mejor estar influenciado por un escritor que por otro pintor" (Ramírez 69). Vale decir, ese oscuro deseo de construir y elaborar un objeto tiene como base la transferencia de saberes. Para Duchamp este saber se unía al poder escenificar una gran máquina. Es lo que se conoce con el nombre de "pintura de precisión".

El soporte pictórico es un vidrio, cristal transparente y luminoso, de pureza inalterable y de rígida tersura. Es como si la frágil realidad fuese vista por medio de infinitos pliegues de sentido, lo que hace visible también el encabalgamiento de la teoría de otros mundos posibles. La visualización del signo artístico es en negativo, o sea, la lectura del texto-cristal da cuenta de "una gran metáfora sobre lo ilusorio de la percepción sensorial y sobre nuestra posible trascendencia en un espacio superior" (Ramírez 73). Aquí funciona la noción de molde (aparición) y la polisemia del signo (multiplicidad de lecturas).

Duchamp pretende desacreditar el dogma de la precisión científica. Esta es la ironía presente en la obra de un pintor-escritor que no se toma la vida en serio. Él busca deconstruir el complejo universo estandarizado de las máquinas.

El vidrio es un texto en intersticio, con una fuerte línea poética y al margen del conocimiento de la verdad científica. Signo expansivo que se halla en la periferia de las palabras y las cosas, desangrando significados visuales.

En una primera lectura, el sexo y el amor son presentados como una fuerza ciega, delirio y ansia escatológica, visto por medio de una interpretación mecánica y anti-romántica del género: metáfora de la irreductible dualidad masculino/femenino.

El relato del panel contiene dos marcos como zonas que delimitan espacialmente el texto: a) marco superior: la novia; b) marco inferior: los solteros. Ambas dimensiones están atravesadas por el tema del erotismo como configurador de un deseo maquínico por acceder a la totalidad inalcanzable. Lo femenino y lo masculino se encuentran en una relación de paralelismo narrativo, mientras la diversidad de imágenes entre ambos espacios ilustran el lenguaje del pensamiento con una percepción erótica en todas sus facetas anti-retinianas.

El espacio masculino da cuenta de un proceso de creación tematizado por capas semánticas en yuxtaposición transparente, que parodian la eterna circularidad masturbatoria de la máquina humana. Este movimiento repetitivo y monótono gira y avanza en pliegues eróticos. Entraña un derroche energético que se consume mediante la expresión vida lenta / círculo vicioso / onanismo / horizontalidad / tope de vida / vida soltera. Por ejemplo, el molinillo de chocolate es una metáfora masturbatoria, adición perversa a la práctica de la sexualidad normal y exhibición de una carencia original. 
La moledora de chocolate escenificada en el marco de la soltería posee una fuerte huella alegórica, que resume el concepto de Gran Vidrio. El soltero muele su propio chocolate como una premisa onánica de autosatisfacción sexual por excitación artificial. En cambio, la novia virginal se expande y emite sus signos de aceptación con la puesta al desnudo, accionado eléctricamente por los solteros.

Con estos artefactos no se trata de reconocer el vínculo directo entre las palabras y los objetos, sino de re-situarlos en los límites de lo posible e insinuar el lenguaje de la deriva mediante el murmullo incesante de la transgresión de lo visible, aventurando la evocación metafórica y el acto de transmutación del objeto monogámico a una estampa artística que posee la huella poética de lo original. Es la visualización cerebral y el lenguaje del pensamiento alusivo a los artefactos /el trineo/, /la rueda/, / la cascada invisible/, /el molinillo/ y /las tijeras/. Todos ellos constituyen una máquina autónoma, que no tiene mayor contacto con el circuito energético masculino y que se proyecta en el marco espacial de "la novia". Se podría decir que el género masculino (los solteros) está sometido al campo de gravitación del género femenino (la novia). Por otra parte, los moldes málicos dentro del cuadro (grafismo pictórico equivalente a la escritura) es un antifaz (vaga apariencia antropomórfica) de la máquina soltera cuya connotación semántica alude a una energía erótica que se oculta en el onanismo masculino. Esto, en el plano del descrédito irónico de las máquinas. Conjuntamente con esta matriz de Eros está el tobogán por donde se desliza el chocolate triturado por los solteros y los testigos oculistas, que es el resplandor panóptico que vigila la salpicadura masculina. Según Duchamp, en Duchamp du signe, con los moldes, tamices y la espiral elíptica, se pone en cuestión la apariencia y surge el principio de la aparición en superficie. La apariencia es el conjunto de datos sensoriales 'ordinarios' que permite hacerse una idea del objeto. En cambio, la aparición es la imagen en $\mathrm{n}-1$ dimensiones de los puntos esenciales del objeto, o sea, es un molde que facilita la construcción del objeto, y es el reverso o interior de la imagen de un objeto (108).

Con el Gran Vidrio se concibe un sistema de pensamiento diferente. Lenguaje cerebral que permite inventar mecanismos que se unen por encabalgamientos de sentidos. En el fondo, se desplazan semánticamente hacia ámbitos de proximidad. Hay una lógica poética emparentada con los procesos de transmisión metafórica que hace posible "otra" lectura: el Gran Vidrio como mecanismo amatorio. Metátesis icónico-mecánica que oscila entre el mundo material de los solteros (estampa inferior y tridimensional) y el universo liberado de la novia (estampa superior, cuatridimensional, vía láctea o novela de anticipación).

El espacio femenino presenta el artilugio de la mujer artificial (apariencia de la casada al desnudo), que por extensión temática se aproxima a la figura de Frankenstein²:

2 Metáfora patética del drama de nuestro tiempo: los objetos o sus símbolos se han impuesto sobre las personas, donde las criaturas esclavizan a los creadores, donde se fragmenta todo y se descartan los objetos y las personas. 
organismo alargado y de aspecto horizontal que despliega el sentido de la artificialidad del cuerpo de la mujer ${ }^{3}$. Soporte y fondo de una escritura erotizada.

La comunicación entre la novia y los solteros se produce mediante el contacto de fluidos energéticos. Los femeninos discurren hacia abajo como una cascada de erotismo, y los masculinos suben verticalmente. Es el juego entre la apariencia de un objeto con el conjunto de datos sensoriales y la aparición en superficie de una imagen que posee la transparencia a partir del molde anti-retiniano (el negativo). En este punto surge el texto como una espiral de significados alusivos al concepto de género y poder maquínico. La apariencia maquínica se expande metafóricamente hacia otra dimensión del mundo concebida como vía láctea, en un proceso que transita de la geometría a la anatomía humana a través de las connotaciones semánticas y de un saber que deriva también hacia la novela de anticipación.

El deseo de Duchamp era lograr con el Gran Vidrio una pintura de precisión que narrara la belleza de la indiferencia maquínica de los artefactos de acuerdo a los siguientes pliegues de sentido: a) marco temático 'la novia tenía que ser desnudada'; b) hacer visible la invisibilidad de lo impensado (punto de fuga); c) el lenguaje del pensamiento cerebral; d) la ironía como elemento desacralizador de los moldes maquínicos. Todos estos pliegues convergen al sentido figurado del cristal: un "sistema solar" que connota semánticamente la metáfora del amor, más la cuarta dimensión de la novela de anticipación anti-retiniana por medio de un montaje ilusionista.

Para Duchamp el Gran Vidrio es el relato metafórico "sobre la naturaleza inexorablemente mecánica del amor" (Ramírez, Duchamp el amor y muerte, incluso 143). Por encabalgamiento adverbial, también es la escenificación de una colmena transparente. En la estampa inferior están los zánganos, brindando el éxtasis de su amor, y a su vez, esperando el momento de la muerte ritual. Mientras que en la estampa superior, la novia absorbe a estos amantes ilusorios como mantis religiosa que decapita los moldes málicos hasta devorar el cuerpo masculino en el acto de mayor erotismo.

El texto presenta pliegues encabalgados: metáfora del amor, incluso fabulación de una tragedia. Más aún, es el lugar donde yacen las ideas planetarias (ready-made) mediante un movimiento giratorio que caracteriza la autenticidad del programa narrativo. Este programa está hecho de un conjunto de máquinas y utensilios diversos, unidos por la presencia en un mismo nivel espacial. Esto justifica la lectura parcelada de los artefactos.

Desmontar la escritura de una verdadera novela de anticipación en capítulosobjetos es re-armar el "sistema solar" y la discursividad del texto pictórico a partir de un descentramiento de la lectura. Esta lectura despliega sentidos imaginarios y otorga simbólicamente a la elaboración del Gran Vidrio las propiedades objetuales -yuxta-

3 Novia puesta al desnudo gracias a la electricidad (momento clave de la representación erótica). De ahí, que el cuadro tenga algo de máquina de exhibición. 
puestos en forma heterogénea- en su deriva connotativa o virtualidad plausible. En consecuencia, es una obra abierta e inconclusa. Un sistema de signos polivalentes.

En el fondo, el Gran Vidrio - relato de anticipación - narra la aventura amorosa desde un nivel maquínico. El desciframiento de los diversos episodios sitúa a los personajes en su entorno cambiante: la novia y su apoteosis de virginidad, la máquina soltera y lúbrica que se traduce en onanismo y erotismo, máquina deseo y engranaje lujurioso. El nexo entre los solteros y la novia será por vía eléctrica. De esta manera, se expresará la puesta al desnudo de ella y su expansión del deseo imaginativo. Vale decir, hay un desplazamiento de los límites de lo posible. Ahora las fronteras del lenguaje auguran un cuadro en bisagra: estampa superior / inferior; máquina / hombre; pintura / literatura; visible / invisible; escritura / lectura; palabras / objetos; apariencia / aparición; vía láctea / novela de anticipación.

J. A. Ramírez señala que la historia del texto tiene un final feliz con la comunicación permanente de ambos sexos en la verosimilitud del "69" (Duchamp el amor y muerte, incluso 141, 168 y 190). Metáfora circular del amor y erotismo en el laberinto argumentativo de la máquina inscrita en el vidrio: un cuadro de bisagra que se identifica con el marco y los dos cristales, formando una ventana con pliegues de ilusión. En la enunciación del vidrio está el enunciado de los artefactos, con un narrador indeterminado.

Por último, la Caja Verde (1934) como catálogo maquínico transportable y museo en miniatura y portátil es un gozne rotatorio de palabras e imágenes que establece las condiciones del lenguaje en el sentido de que la caja es un espacio de escritura o signo emancipado en el marco del "sistema solar" como obra abierta y sus respectivos "planetas" (el Gran Vidrio + ready-made). En este museo devienen tres paradigmas: el registro, la identidad y la intimidad. El registro tiene que ver con el testimonio y recuperación de imágenes. La identidad y la intimidad forman una especie de 'corpus' como soporte del relato. Por eso, el acto pictórico resumido en esta caja es una verdadera cirugía de resurrección de las palabras, las imágenes y las cosas. En este sentido, tiene el pliegue de la convocación, la preservación y la trascendencia en el tiempo: cajamemoria. Etant donnés es la versión hiperilusionista del Gran Vidrio, o sea, la versión más sensual. Aquí se aclara la posición del autor ante la vida: reafirma el papel central del erotismo en su obra. El amor es el motor del mundo, que está dentro de nosotros y al otro lado de la puerta: lo visual es un resorte ilusorio de lo mental. El mirón es el personaje central de la materialidad de la puerta que se abre a la ilusión del cerebro.

\section{Cuarta reflexión: lectura en bisagra Martínez / Duchamp}

Juan Luís Martínez (1942-1993) trabajó nueve años en la construcción de La Nueva Novela (1968-1975), buscando formular un nuevo sentido al acto de poetizar a través de la re-escritura de la literatura, el discurso y el texto. Él deconstruye los modos canónicos de hacer poesía, pone en cuestión la realidad mediante la lógica del absurdo 
y prescinde de la narratividad lineal en beneficio del concepto de obra abierta. Signo polisémico que favorece una multiplicidad de lecturas a partir del desciframiento y desmontaje que el lector cómplice realiza en la constitución de la obra y en la inscripción de sus relaciones de distintos saberes. En este sentido, nos encontramos con un texto que posee una bolsa cultural lingüística, intertextual y enciclopédica que el lector debe activar por medio de una lectura presuposicional móvil y/o cruzada. Múltiples direcciones, propio de un texto rico en referencias.

La Nueva Novela articula la polisemia y ambigüedad de significados. De este modo, es una obra abierta que se resiste a ser leída como un todo finito. No es una obra absoluta, sino un trazado que confirma la deconstrucción del logos (conocimiento) por medio de un sistema inhabitual de representación como el juego de las contradicciones en el plano de la intelectualidad experimentadora y creadora. Esto a la luz de una escritura que tiene el espaciamiento de un collage semiótico laberíntico, ajeno al discurso convencional. Por ejemplo, la portada es un marco (paratexto) que da cuenta de una imagen fotográfica que está en el límite de lo posible (casas, ¿cayéndose?), en un espacio entre el afuera (extratexto) y el adentro (texto), indicando la fragilidad e inestabilidad de los cimientos de La Nueva Novela. Base troquelada por diversos saberes.

El proyecto escritural de Juan Luís Martínez se inscribe dentro de la poesía neovanguardista de acuerdo a la búsqueda de nuevas posibilidades de configurar el significante (en la composición interviene la disposición, el soporte iconográfico y la tipografía), la incorporación de elementos no verbales (objetos y artefactos), la expansión del texto y el intento de crear nuevas relaciones entre los signos, los significados y el referente. Ruptura y transgresión como fondo de obra.

Con La Nueva Novela se plantea "otro" tipo de texto. Un texto significante constituido por distintos discursos, fotografías, objetos (anzuelo, bandera), que juegan a contradecirse y a inter-relacionarse en un intento de mostrar la inexistencia del sentido y la inconsistencia de lo real. Hay una resonancia irónica producida por las palabras, espacios, diagramas, ilustraciones y dibujos, en razón a una incesante exploración en el mundo de los signos. Él mismo escribe su nombre, pero luego lo tacha para que el sujeto-autor desaparezca. En el fondo, se trata de realizar una lectura desde el referente de la pintura duchampiana. Desplazamiento que nos remite a leer sobre la base de los procedimientos (no el resultado o el producto) de la actitud analítica del desmontaje, de des-habituar los hábitos canónicos del lector, produciendo perplejidad en la composición de la página. Por ello, el collage y el montaje usados para la deconstrucción del discurso visual es un acto de evocación del método empleado por Duchamp por vía de la disociación lingüística. Además, La Nueva Novela y el Gran Vidrio poseen la huella tautológica del objeto indicial, que se nombra a sí mismo.

Esta obra de Martínez está elaborada con el apoyo de textos sobre textos. Se convierte en un texto-imagen y artefacto visual, que induce a ver la escritura a través de figuras geométricas y fotografías en negativo como una modificación del lenguaje y alteración de la convencionalidad del acto de poetizar. Es un juego entre la inteligencia 
y la artesanía manual. Vale decir, pone en crisis la noción de límite y género. Esto es un verdadero gozne giratorio entre Martínez y Duchamp en la idea de la escenificación del desplazamiento entre las relaciones habituales de los objetos y su designación.

Ambos problematizan la construcción de la obra en un movimiento que pone en evidencia "lo mental" (molde y aparición en superficie) por sobre la fisicalidad (apariencia sensorial del objeto ordinario). Por lo tanto, la noción de transparencia está en que no interesa la materialidad como unidad superficial, sino el funcionamiento y el proceso. En otras palabras, ponen en escena la auto-reflexividad de la construcción de la obra.

El proceso que sigue la escritura de Juan Luís Martínez en su intento de poner en crisis la linealidad del lenguaje se manifiesta en el encabalgamiento de fragmentos lingüísticos y de imágenes visuales que sirven de corrimiento del significado al significante. La deconstrucción del discurso visual escenifica la ruptura de arte-realidad y plantea la reformulación de los saberes. Esta huella de desmontaje opera en un espaciamiento de múltiples remisiones y recorridos en la re-elaboración del lenguaje, donde se pone en duda la representación y se relativiza la certidumbre de la lectura (autonomía del lenguaje + autogeneración del texto).

En La Nueva Novela hay cuatro temas-bisagras con respecto a Duchamp: el rol del lector (cómplice), el concepto de autor (iconoclasta, cerebral y anónimo), la elaboración del texto (proceso intelectual, mundo de las ideas) y la función de las palabras y las cosas (lo impensado).

En 'La página siguiente' se ilustra la situación del lector: él con su lectura es el constructor de la obra. El concepto de autor aparece en 'Tareas de poesía': si el lector está comprometido con la interpretación del texto, el autor deja de tener contacto con él debido a la "rara" expresión del lenguaje, es decir, autor y texto están implicados sólo en la recepción del lector. En consecuencia, la constitución del texto se sitúa en la mente del destinatario. Por último, una de las claves del libro está en los homenajes a Mallarmé dispersos por todo el texto, especialmente en el poema 'El cisne troquelado', donde la función de las palabras tiene el impensado juego semiótico sobre el signo y el acto de significar más el grado cero de presencia formal del hablante.

En una entrevista que tuvo con Félix Guattari el 19 de mayo de 1991-El devenir de la subjetividad - señala que "Ahora, mi mayor interés es la disolución absoluta de la autoría, la anonimia, y lo ideal, si puede usarse esa palabra, es hacer un trabajo, una obra, en la que no me pertenezca casi ninguna línea, articulando en un trabajo largo muchos fragmentos, pedacitos que se conectan. Es un trabajo de Penélope.” (148).

Esta obra no sólo subvierte, sino también propone un nuevo modo de pensar, leer y mirar tanto los procedimientos de expansión del significante como la incorporación del extra-texto. En este sentido, la elaboración del dispositivo (libro artefacto) incorpora la manualidad maquínica, hojas intercaladas, anzuelos y otros elementos que materializan el texto como un bricolage en el que se recontextualiza un repertorio de materiales heterogéneos distante de su uso original. El montaje de estos materiales diversos relacionados con la crisis de la representación hace de La Nueva Novela un 
libro-objeto sustentado en la noción de bricolage que, en el fondo, reitera otro concepto: la auto-reflexividad en tanto que desplaza el libro de sus relaciones habituales. En este sentido, nos encontramos con dos pliegues de sentido deconstructivo y transgresor: a) es un texto hecho por medio de la re-escritura de otros textos (transferencia de saberes); b) es un texto significante desde su conformación material hasta la asunción de fragmentos literarios, culturales e históricos (la fotografía, el título, el nombre del autor tachado dos veces, la contratapa, los dibujos interiores, collages, los objetos y documentos incluidos, los discursos visuales y verbales). En el fondo, es una forma de armar una lectura con "un fondo documentario de obra y biblioteca como soporte" (Nordenfliycht 22) de objetos contenedores de sentido.

$\mathrm{Al}$ igual que la pintura literaria de Duchamp, la construcción de La Nueva Novela se realiza por medio de un lector cómplice que desentraña las referencias e inserciones textuales (solapas, portada y contraportada, etc.) en el marco de claves, remisiones y posibilidades de lecturas cruzadas, que dan cuenta de la precariedad y ambigüedad de la significación. Evidentemente, nos encontramos con elementos surrealistas y dadaístas como un absurdo que traza el factor desalienante del texto. Esto, en relación con una vanguardia considerada como fuente, que trabajaba, como dice Nordenflycht, con el imaginario del concepto, no con la ilusión de rentabilidad (28).

Por otra parte, el proyecto escritural de Martínez resiste una lectura desde el referente duchampiano en el sentido de que ambos insertan el concepto de la metarealidad. La transparencia del proceso tiene la deriva de la aparición en superficie del molde del objeto recontextualizado. Vale decir, la apariencia 'ordinaria' del objeto pierde su valor de representación originaria. Es la mirada fisurizada y en intersticio proveniente de la dimensión intelectual, que es el gozne crítico y metapoético, propio de una escritura que hace del diferimiento la huella diferencial de la precariedad de la vida, según el principio neoplatónico del mundo ilusorio y la dimensión cerebral del acto de construir y elaborar la aventura de la transgresión.

La lectura de La Nueva Novela pasa por la noción de para-texto, que es el umbral entre el adentro y el afuera (texto y extra-texto) como franja que orienta la percepción del marco: título, epígrafe, prólogo, colofón; portada, contraportada y solapas. Como en la obra de Duchamp, se da una impresión de unidad a partir de la fragmentación. Desde esta mirada, propongo comenzar a leer esta obra desde el final, específicamente desde las Notas y Referencias (Nota 2,3 y 5) porque en este nuevo modo de leer el texto encontramos la concepción meta-poética del mundo que sustenta el poeta.

Nota 2: El hablante concibe su actitud ante el mundo de acuerdo al gozne intertextual de Alicia de Lewis Carroll: maravilla, extrañeza y temor. Las sorpresas con que se encuentra el lector define el texto sorpresa, que constituye La Nueva Novela como lógica de un humor metafísico y grotesco: juego entre la risa y tristeza del hombre. El contemplador del texto siente la ambigüedad de una escritura metapoética.

Nota 3: El gozne entre ser y expresión se abre a una ilimitada expresividad textual como una manera de subvertir el encadenamiento al ciclo binario vida/muerte. 
Murmullo incesante que deriva hacia el placer transgresivo del texto. Exteriorización de la voluntad de sonreír que tiende hacia el develamiento de la trágica realidad del dualismo, en base a la inexpresividad de la sonrisa. En este sentido, la "novela" es un texto paradoja, que suscita la impresión de la des-realización del mundo y del carácter precario de la realidad humana a través de la enigmática y misteriosa expresividad del gato de Cheshire II.

Nota 5: El inarticulado lenguaje de los pájaros o Confabulación Fonética se expresa en algunos escritores en la irracionalidad del silencio. Así como los pájaros viven atrapados en el canto como el lenguaje del ser, los poetas saben que también viven en un abismo entre el lenguaje y el orden del mundo. Ambos han perdido su centro y deconstruyen en silencio. Unos, cantando en todas partes; otros, lenguajeando restos del logos: los dos, dispersos. Sin embargo, no es el canto de los pájaros ni la palabra humana, sino el silencio el que se convierte en mensaje con el fin de establecer, prolongar o interrumpir la comunicación mediante los oídos de los hombres ('Observación relacionada con la exuberante actividad de la Confabulación Fonética o Lenguaje de los Pájaros en obras de J. Brisset, R. Roussel, M. Duchamp y otros'). Por lo tanto, la "novela" es un texto concebido como expresión de lo inefable.

En resumen, el texto sorpresa, el texto paradoja y el texto inefable son las líneas de intensidades que sintetizan el texto artefacto de La Nueva Novela de Juan Luis Martínez, que en una articulación en bisagra, podemos transferir a la obra visual de Marcel Duchamp anteriormente estudiada: de lo visible a lo invisible está la puesta en escena de la noción apariencia/aparición como elemento de transparencia textual entre Martínez y Duchamp. Cruce de la literatura pinturizada y la pintura literaturizada, gozne que revela la meta-realidad y la meta-poética de ambos, en un juego entre manualidad y reproducción mecánica. Si uno pone en crisis la noción y codificación de la poesía, el otro pone en cuestión la narratividad del título en una deriva hacia la re-designación y re-contextualización de los objetos. En los dos, la mirada del signo artístico posee el lenguaje de la radicalidad que notamos en la transversalidad de saberes discursivos, en la reflexión fragmentaria y deconstructiva, en las referencias mallarmianas como murmullo rupturista. También ambos trabajan el concepto de construcción de obra, plantean el rompimiento con el marco de la poesía y de la pintura (noción de límite y género) de acuerdo con un dispositivo analítico que oscila entre la idea como conceptualización y la ejecución como procedimiento técnico. Vale decir, ambos se abocan a una reflexión metalingüística de la obra de arte. Por último, Martínez y Duchamp se mueven entre la sombra (un texto que oculta otro texto) y la iluminación (hacer luz los elementos invisibles), sustentado en la noción creativa del arte mental y en un juego silencioso de cruces, transferencias y recorridos que pone en escena el tema de la modernidad como discursividad del arte contemporáneo en el devenir de la subjetividad. Además, ambos derivan hacia una lectura de la reconstrucción como soñadores que inventan su propia gramática: yuxtaposición, desplazamiento y suspensión del discurso lineal son las figuras alegóricas de la escritura de Martínez y Duchamp. 


\section{Referencias}

Barthes, Roland. El placer del texto y lección inaugural. México: Siglo XXI, 1986. Medio impreso.

Brihuela, Jaime. "Las vanguardias artísticas: teorías y estrategias". Historia de las ideas estéticas y de las teorías artísticas contemporáneas. Madrid: Visor, 1996. Medio impreso.

Deleuze, Gilles y Felix Guattari. El anti-Edipo. España: Paidós, 1995. Medio impreso. Duchamp, Marcel. Escritos Duchamp du Signe. Barcelona: Gustavo Pili, 1978. Medio impreso. Fernández Alba, Antonio et al. "El artista poeta: Marcel Duchamp". Arte y escritura. España: Universidad de Salamanca, 1995. Medio impreso.

Ferro, Roberto. Escritura y deconstrucción. Lectura (h)errada con Jacques Derrida. Buenos Aires: Biblos, 1995. Medio impreso.

Foucault, Michel. Del lenguaje y literatura. I.C.E. de la Universidad Autónoma de Barcelona: Paidós,1996. Medio impreso.

---. Las palabras y las cosas. México: Siglo XXI, 1968. Medio impreso.

Guattari, Félix. “Conversación con Juan Luis Martínez". El devenir de la subjetividad. Santiago: Dolmen, 1998.

Jauss, Hans Robert. Las transformaciones de lo moderno. Estudios sobre las etapas de la modernidad estética. Madrid: Visor, 1995. Medio impreso.

Jiménez, José. "Marcel Duchamp y la experiencia estética de la modernidad". La vida como azar. Mandadori. 1989. Medio impreso.

Martínez, Juan Luis. La Nueva Novela. Santiago: Archivo, 1985. Medio impreso.

Mink, Janis. Marcel Duchamp, 1887-1968, El arte contra el arte. Germany: Taschen. 1994. Medio impreso.

Monarca, Patricia. Juan Luis Martínez. El juego de las contradicciones. Santiago: RIL, 1998. Nordenflycht, José de. El gran solipsismo. Juan Luis Martínez. Obra visual. Valparaíso: Puntángeles, 2001. Medio impreso.

Moure, Gloria. Marcel Duchamp. Barcelona: Polígrafa. 1988. Medio impreso.

Paz, Octavio. Los hijos del limo. Barcelona: Biblioteca de bolsillo, 1990. Medio impreso.

---. Apariencia desnuda. La obra de Marcel Duchamp. Madrid: Alianza, 1991. Medio impreso.

Pérez Carreño, Francisca. Los placeres del parecido. Ícono y representación. Madrid: Visor, 1988. Medio impreso.

---. "El signo artístico". Historia de las ideas estéticas y de las teorías artísticas contemporáneas. Madrid: Visor, 1996. Medio impreso.

Pérez Villén, Ángel Luis. "Los pliegues del sentido”. Ponencia presentada en el ciclo sobre Arte y deconstrucción en el Colegio de Arquitectos de Málaga, 1995.

Ramírez, Juan Antonio. Arte y arquitectura en la época del capitalismo triunfante. Madrid: Visor, 1992.

---. Duchamp el amor y la muerte, incluso. Madrid: Siruela, 1993.

Recibido: 14 diciembre 2012 Aceptado: 25 abril 2013 